\title{
12203 バイオマス燃料ディーゼル機関の燃料添加剤に関する研究
}

(セタン価向上剤、燃焼改善剤添加の影響)

The Effects of Fuel Additives on Exhaust Emissions and Performance of Diesel Engine Fueled with Biomass-based Oil

\author{
余 力 (湘南工科大学・院) . 森棟 隆昭 (湘南工科大学)
}

Yu Li and Takaaki MORIMUNE

Shonan Institute of Technology, 1-1-25, Tsujido Nishikaigan, Fujisawa, Kanagawa

\begin{abstract}
We experimentally evaluate a performance and exhaust emissions of a single-cylinder, four stroke direct injection diesel engine operating on diesel fuel containing $50 \%$ volume waste food-oil (Blend 50 ) as tested fuels. The combustion characteristics, emissions such as $\mathrm{NOx}, \mathrm{CO}, \mathrm{O}_{2}, \mathrm{CO}_{2}$ and smoke were compared with the case of JIS \# 2 diesel fuel. Experimental results indicated that the Blend 50 were usable as alternative fuel for diesel engine and Blend $\mathbf{5 0}$ were available for a treatment process of the waste food-oil. In present study, fuel additives such as cetane improver and combustion improver were used for improving the combustion efficiency and reducing the unburned component in exhaust.
\end{abstract}

Key words : Diesel Engine , Biomass-based Fuel, Exhaust Emission, Fuel Additives, Cetane Improvers

\section{1.まえがき}

本研究では、年間 40 万トン以上排出される廃食用油の 適正な処理処分法の検討を目的としている。

これまで、軽油に天ぷら廃油を混合したブレンド油など バイオマスブレンドのリサイクル燃料を提案し(1)、ディー ゼル機関に使用した場合の機関性能および排ガスの環境特 性を求めて軽油の場合と比較してきた。これよりリサイク ル燃料のセタン価がやや低いことや排ガスの NO x 濃度が やや高い短所はあるが、機関性能や環境特性に大きな問題 はなく、ディーゼル燃料として使用できると共に、環境に 対する負荷の大きい廃食用油を適正に処理できる可能性が あることを考察 (2) した。

本報告では上記バイオマスブレンドディーゼル燃料にセ タン価向上剤や燃焼改善剤を添加することにより、ディー ゼル機関の性能や排ガス中の有.害成分の排出を低減するこ とで環境特性を更に向上させることを試みた。

2. ディーゼル機関実験装置と燃料油の特性

2 . 1 実験装置と測定法

実験には Fig. 1 に示す実験装置を使用した。水冷単気筒 ディーゼル機関（総行程容積 $411 \mathrm{cc} 、$ 直接噴射式、定格出 力 $5.1 \mathrm{~kW} / 2400 \mathrm{rpm}$ 、圧縮比 18 ）を用い、電気動力計に より機関の負荷を $28 １ 00 \%$ と変えた。機関の回転速度は $2300 \sim 2600 \mathrm{rpm}$ とし、吸排気系、燃料供給系や冷却、潤 滑系などは標準仕様から変更していない。燃料は廃食用油 として天ぷら廃油と軽油を混合したブレンド油（Blend 50)、およびJIS 2 号軽油（Diesel fuel）の 2 種類を用い、 ベース燃料のブレンド油に添加物を混入させ供試機関を負 荷運転して、それぞれの然料における機関性能や排ガス特 性を求めた。

ジリンダヘッドには、ひずみゲージ式圧力変換器（容量 $9.8 \mathrm{MPa}$ 、固有振動数 $37 \mathrm{k} \mathrm{Hz}$ ) を装着しており、シリンダ の圧力值を計測した。供試機関の排気管出口における排気 ガス中の各成分の体積濃度については、NO x を化学発光 法、CO を非分散形赤外線吸収法で測定した。排気ガスの スモーク濃度測定には排気管出口においた透過式スモーク メータを用いている。運転時の燃料消費量の測定より燃料 消費率を求めている。

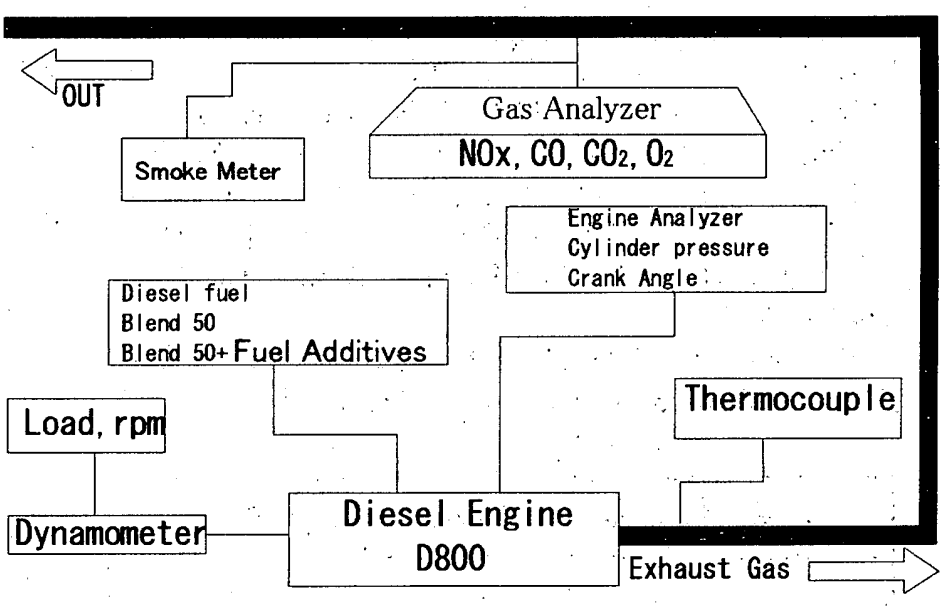

Fig.1 Experimental apparatus of diesel engine operated on diesel fuel, biomass based fuel.

\section{2 廃食用油燃料の製油と燃料分. 析}

廃食用油として本大学食堂にて数回の使用後排出された 天ぷら廃油を用いた。天ぷら油の主成分は大豆油である。 この天ぷら廃油を前処理として定量ろ紙 5 種 A (JIS P 3801）を用いて異物除去した後、オーブンにて $110^{\circ} \mathrm{C} て ゙ 1$ 時間加熱して水分を取り除き、軽油と混合して実験に使用 した。天ぷら廃油と軽油を体積比 $1: 1$ で混合したブレン ド油（Blend 50）を製油した。天ぷら廃油と軽油の溶解性 は極めてよく、単純に混合するだけで燃料として使用可能 である(1)。

Table 1 に本実験で用いたてんぷら廃油、Blend 50,及び 軽油の分析結果を示す。燃料油の動粘度、セタン指数、発 熱量、残留炭素分、灰分、水分などの諸特性はJIS 規格に 沿って分析している。また元素成分については元素分析計 を使用して求めた。セタン指数については、JIS K 2280 を 用いて常圧蒸留試験 (JIS K2254) 結果より算出している。

Table 1より Blend50 の動粘度が軽油と比較して約 3.5 倍であること、セタン指数が軽油よりやや低いこと、燃料 中に約 $6 \%$ の酸素を含む含酸素燃料であることなどが確認 できる。 
Table 1 Fuel properties of tested oil

\begin{tabular}{|c|c|c|c|c|}
\hline Properties & Fuel & Diesel fuel & Blend 50 & Temp \\
\hline Flash point & ${ }^{\circ} \mathrm{C}$ & 68 & 80 & - \\
\hline $\operatorname{Density}\left[30^{\circ} \mathrm{C}\right]$ & $\left(\mathrm{kg} / \mathrm{m}^{3}\right)$ & 836 & 883 & 927 \\
\hline Viscosity $\left[35^{\circ} \mathrm{C}\right]$ & $\left(\mathrm{mm}^{2} / \mathrm{s}\right)$ & 3.25 & 11.49 & 42.37 \\
\hline Cetane index & & 54.6 & 48.0 & - \\
\hline Lower C. V. & (MJ $/ \mathrm{kg})$ & 43.50 & 39.83 & 38.1 \\
\hline Carbon residue & $\left(w t^{*}\right)$ & 0.01 & 0.19 & - \\
\hline Carbon & $c(w t \%)$ & 86.0 & 81.3 & 77 \\
\hline Hydrogen & $h(w t \%)$ & 13.8 & 12.5 & 12.0 \\
\hline Oxygen & $o(w t \%)$ & $\leq 0.1$ & 6.1 & 11.0 \\
\hline Nitrogen & $n(w t \%)$ & $<0.1$ & $<0.1$ & $<0.01$ \\
\hline Sulfur & $s(w t \%)$ & 0.02 & 0.01 & $<0.01$ \\
\hline Ash & $a\left(w t^{\%}\right)$ & $<0.01$ & $<0.01$ & - \\
\hline Water & $w(w t p p m)$ & 100 & 200 & 810 \\
\hline
\end{tabular}

\section{3 燃料添加剂}

硝酸エステル、有機過酸化添加物などにセタン洒向上効 果があることが知られる。本研究では、セタン価向上剂と して硝酸エステル類の硝酸アミル $\left[\mathrm{CH}_{3}\left(\mathrm{CH}_{2}\right)_{4} \mathrm{ONO}_{2}\right]$ を、燃 焼改善剤としては、高濃縮、安定した有機バリウム[Ba]を 添加した。硝酸アミルは着火温度の低下により着火遅れを 短かくし、バリウムは燃焼促進剤であり燃焼効率の上昇に よって CO、HC などの不完全燃焼排出物質の低減効果が 期待される。

Table 2 に Blend 50 に上記燃料添加剂を添加した燃料 Blend 50 +Amyl Nitrate と Blend 50+Ba を示す。

Table 2 Tested fuels

\begin{tabular}{|c|c|c|}
\hline Test fuel & Base fuel and Additive agent & Rate \\
\hline \multirow{2}{*}{ Blend 50+Amyl } & Cetane improver(Amyl) & 1500 ppm \\
\cline { 2 - 3 } & Blend 50 & Resictual quantity \\
\hline \multirow{2}{*}{ Blend 50+Ba } & combustion improver(Ba) & 1500 ppm \\
\cline { 2 - 3 } & Blend 50 & Resicual quantity \\
\hline
\end{tabular}

3．機関性能、排ガス特性の測定結果および考察

Fig.2 に硝酸アミルの場合の機関負荷率に対する、排気 管出口における排ガス中の NO x,CO 濃度を示す。軽油よ り NOx 濃度がやや高い Blend 50 に燃料添加剂を添加す ることで、NO x 濃度は減少する。これは、指圧線図から 考察してセタン価向上剂の添加により着火遅れ期間が減少 することで、それに伴う燃焼温度の低下により NOx濃度 が低減したと考えられる。CO 濃度については、低負荷に おいて硝酸アミルによる効果が見られた。Fig.3に燃料消 費率の比較を示す。セタン価の向上により、燃焼が促進さ れ、燃料消費率が減少したと考えられる。Fig.4 に熱効率 の比較を示す。なお、硝酸アミルを添加した場合の低発熱 量は $39.98 \mathrm{MJ} / \mathrm{kg}$ であった。エンジン内の燃焼状態が促進 されたことで、熱効率が向上したと考えられる。

燃料改善剂として有機バリウムを添加したことにより NO $\mathrm{x}$ 濃度が下がった結果が得られたが、詳細については 講演当日述べる。

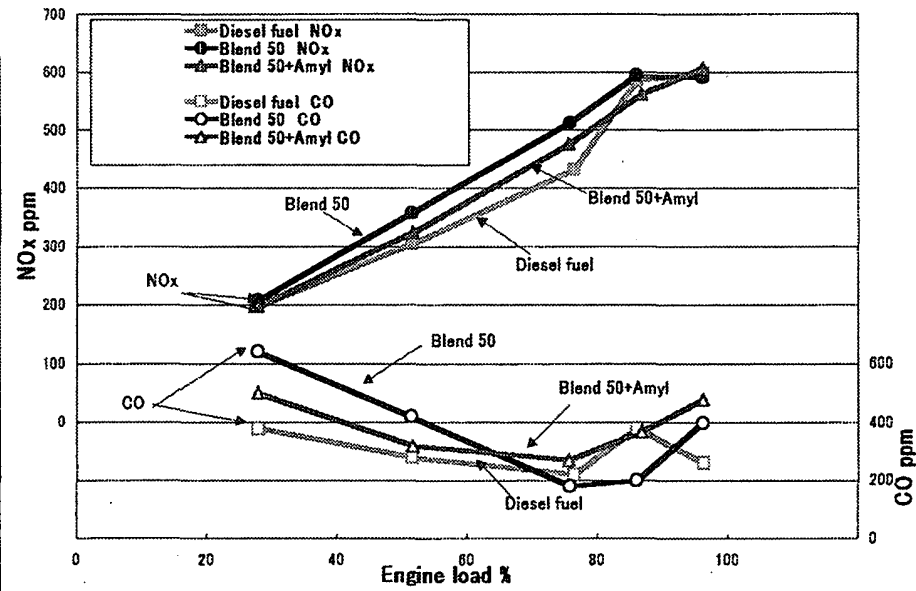

Fig.2 NOx, CO concentrations

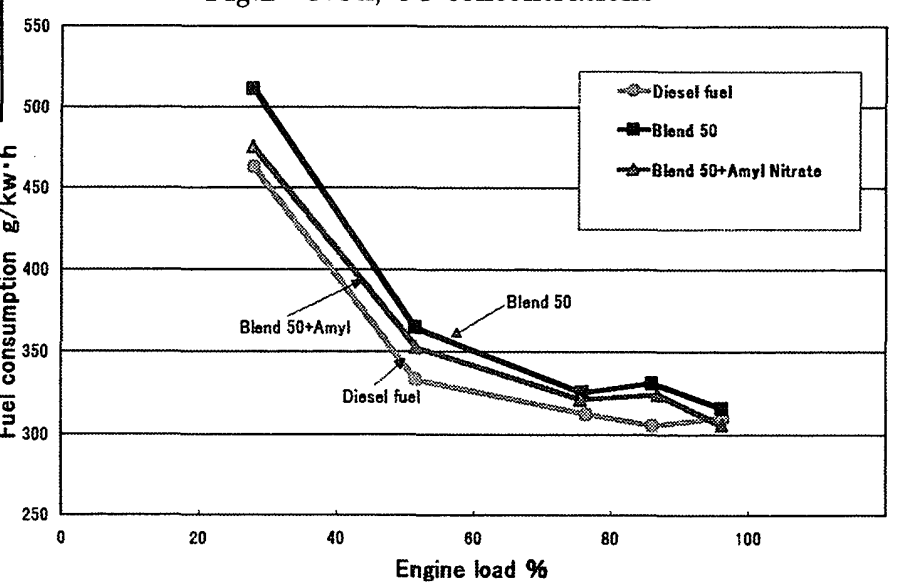

Fig.3 Comparison of fuel consumption

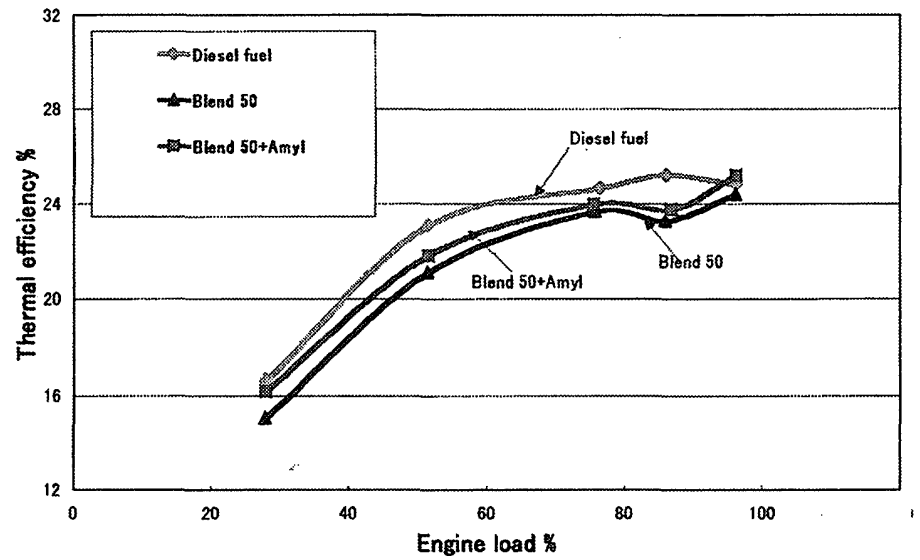

Fig.4 Comparison of thermal efficiency 4.まとめ

本実験ではバイオマスブレンドディーゼル燃料にセタン 価向上剂や燃焼改善剤を添加することにより、ディーゼル 機関の性能や環境特性を向上させることを試みた。

これより、硝酸アミルや有機バリウムの添加により着火 遅れ期間の減少、それに伴う燃焼温度の低下による NO x 濃度の低減や、燃焼促進効果により燃料消費率が下がり、 熱効率が向上したことが確認された。

終わりに、本研究に協力した西澤功生君、沼野井佳敬君 に感謝する。

参考文献

（1）森棟ほか、日本機械学会論文集、66-641, B(2000).

(2) 余力、日本機械学会第 13 回環境工学シンポジウム 講演論文集、(2003). 